\title{
Efforts to Improve Mudharabah Finance of Sharia Commercial Banks through Third Party Funds and Return on Asset
}

\author{
Adetia Azmi Tanjung, Hajar Affiah ${ }^{2}$ \\ ${ }^{1,2}$ STIE Muhammadiyah Asahan, Indonesia \\ tia.tanjung92@gmail.com
}

\begin{abstract}
The main focus of this study is to analyze the effect of both partial and simultaneous third party funds and return on assets on mudharabah financing at Islamic Commercial Banks. The approach used in this study is a quantitative approach, because the data measurement uses a numerical scale (numbers). The population and sample in this study are the financial statements of Islamic Commercial Banks containing third party funds, return on assets and mudharabah financing. The years 2016 to 2019 were chosen as the sample for this study. The results showed that partially only third party funds had a positive and significant effect on mudharabah financing, while return on assets had no effect. Then simultaneously the two variables of third party funds and return on assets have a positive and significant effect on mudharabah financing at Islamic Commercial Banks.
\end{abstract}

\section{Keywords}

third party funds; ROA; financing

\section{Introduction}

Indonesia is a country with the largest Muslim population in the world. Where the opportunity to recognize and promote sharia products certainly has a great opportunity (Mubarokah, 2021). Since the beginning of the emergence of Islamic banks, they have continued to experience fluctuating growth every year, both in terms of assets, the amount of financing disbursed (PYD) and the growth of third party funds (Widardjono, 2021).

The main activity of banks is to channel funds to the public, both conventional banks and Islamic banks. In Islamic banks, the distribution of these funds is more familiarly referred to as financing, while in conventional banks it is often called credit (Wirman, 2021). In general, mudharabah financing products are offered to provide short- and medium-term financing to customers in order to increase capital for business activities run by customers (Sulaeman, 2021). Mudharabah financing used in Islamic banks is principally based on a profit sharing agreement between the Islamic bank (shahibul maal) and the customer (mudharib). The profit sharing agreement obtained can be 50:50, 60:40, depending on the agreement between the two parties at the beginning of the contract/contract.

Problems that often occur in the field, customers are often dishonest about the profits they get so that Islamic banks are often disadvantaged. So to minimize customer dishonesty in obtaining profits, the Islamic Bank per period often monitors business developments and the customer's financial statements. This is done by the Islamic Bank so that the business activities of both Sharia Banks and customers can run well and smoothly. According to the type, Sharia Banks consist of Sharia Commercial Banks and Sharia People's Financing Banks. Sharia Commercial Banks are the largest Islamic banks with business activities spread across all provinces in Indonesia.

There are several sources of funds that can be used to overcome the problems above, including Third Party Funds and Return on Assets. Where Third Party Funds are sources of 
funds obtained from the public and Return on Assets are profits obtained by Islamic Commercial Banks. These two sources of funds can be used as a buffer to absorb losses from non-performing financing, especially mudharabah financing that is being faced by Islamic Commercial Banks. According to Tarigan and Setiawan (2020) The development of bank institutions runs dynamically and has very rapid progress, especially Islamic banking. Ichsan et al (2021) stated that Sharia banking is one of the financial institutions that has the function of balancing, coordinating and coordinating various sectors of the economy.

Sharia Commercial Banks as intermediary institutions or intermediaries for parties with surplus funds to parties with minus funds. In accordance with the functions and principal operations of Islamic Commercial Banks, Islamic Commercial Banks carry out three main functions in community economic activities. The main functions are the function of collecting funds, the function of distributing funds, and services. The following is the development of Third Party Funds, Return on Assets, and Mudharabah financing of Islamic Commercial Banks:

Table 1. Development of Mudharabah Financing, Third Party Funds, and Return on Assets of Islamic Commercial Banks in 2016-2019 (Billion Rupiah)

\begin{tabular}{|l|c|c|c|c|}
\hline \multicolumn{1}{|c|}{ Information } & $\mathbf{2 0 1 6}$ & $\mathbf{2 0 1 7}$ & $\mathbf{2 0 1 8}$ & $\mathbf{2 0 1 9}$ \\
\hline Mudharabah Financing & 7.577 & 6.584 & 5.477 & 5.413 \\
\hline Third-party funds & 206.407 & 238.225 & 257.606 & 288.978 \\
\hline Return on Assets & 1.420 & 1.697 & 3.806 & 5.598 \\
\hline
\end{tabular}

(Source: www.ojk.go.id)

The data above shows a phenomenon that contradicts the existing theory, namely the increase in income through Third Party Funds and Return on Assets is not matched by an increase in the distribution of financing funds, especially mudharabah financing. However, there has been a significant decrease in the distribution of mudharabah financing funds. This causes an imbalance in cash flow that occurs in Islamic Commercial Banks.

The specific purpose of this study is to determine the effect of Third Party Funds and Return on Assets on the mudharabah financing of Islamic Commercial Banks. The urgency of this research is to provide benefits for readers and further researchers to understand the development of Islamic Commercial Banks. Specific specifications related to this research scheme are discussions related to the research topic, namely the development of Islamic Commercial Banks in Indonesia from 2016 to 2019.

\section{Review of Literature}

\subsection{Banks and Banking}

Banking is everything related to banks, including institutions, business activities, as well as methods and processes in carrying out their business activities. Bank is a business entity that collects funds from the public in the form of savings and distributes them to the public in the form of credit and/or other forms in order to improve the standard of living of the people at large. (Kasmir, 2014).

\subsection{Islamic Banking and Islamic Banking}

In contrast to conventional banking in general, Islamic banking offers its operational system and the products offered are in accordance with the guidance of the Qur'an and Hadith (Iska, 2014). Meanwhile, according to (Sudarsono, 2013) Islamic banks are 
institutions whose main business is to provide credit and other services in payment traffic and money circulation which operates in accordance with sharia principles. Therefore, the bank's business will always be related to the issue of money as its main merchandise.

\subsection{Third-party Funds}

Islamic Banks that carry out their functions as intermediary media between Fund collectors and fund distribution have an interdependent relationship because the amount of funds disbursed by the bank depends on the amount of funds provided by the bank through the collection of funds such as Third Party Funds (Tripuspitorin, 2019). Third Party Funds are funds that come from people who do financing, or save, with various deposit products owned by banks (Romdhoni, 2020). When third party funds are increased, this will have a significant impact on mudharabah financing (Saleh, 2020)(Kurniawan, 2020).

\subsection{Return on Assets (ROA)}

Return on Assets (ROA) is an indicator of the profitability ratio. ROA is a ratio used to measure the bank's ability to obtain overall profits (Yolanda, 2018). In addition, profitability (ROA) is the level of the bank's ability to increase its profits within a certain period (Wildaniyati, 2020). The greater the ROA, the greater the level of profit achieved by the company and the better the company's position in terms of asset use (Mandasari, 2021).

\subsection{Mudharabah Financing}

Financing is an activity in Islamic banks, namely channeling funds to other parties based on sharia principles (Romdhoni, 2020). Furthermore, mudharabah financing is financing that is channeled by Islamic banks to other parties for a productive business (Naf'an, 2014). The quality of financing in Islamic banking can be seen from the NonPerforming Financing (NPF) of the Islamic bank. NPF reflects the risk of financing, the higher this ratio, indicating the quality of Islamic bank financing is getting worse. Financing management is very much needed by banks, considering the financing function as the largest revenue contributor for Islamic banks (Handayani, 2021).

\subsection{Conceptual Framework}

The conceptual framework in this study is illustrated by the chart below:

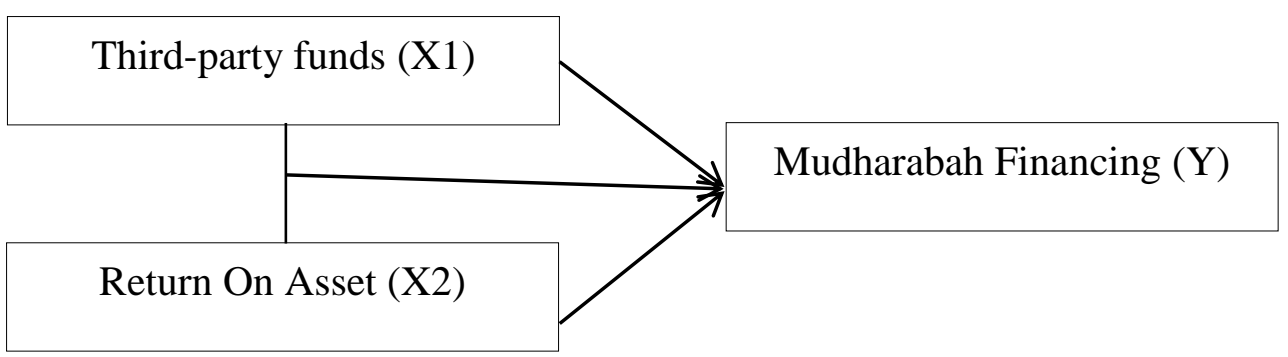

Figure 1. Theoretical Thinking Framework

\subsection{Research Hypothesis}

The hypotheses in this study are:

1. There is an influence of third party funds on the mudharabah financing of Islamic Commercial Banks. 
2. There is an effect of return on assets on the mudharabah financing of Islamic Commercial Banks.

3. There is an influence of third party funds and return on assets on the mudharabah financing of Islamic Commercial Banks.

\section{Research Methods}

The approach used in this study is a quantitative approach, because the data measurement uses a numerical scale (numbers). The population in this study is Islamic Banking Statistics (SPS), which includes statistics on Third Party Funds, Non-Performing Financing, and Mudharabah financing of Islamic Commercial Banks from January 2016 to December 2019 period derived from Islamic Banking Statistics (SPS) obtained from the website Financial Services Authority (OJK) with the link www.ojk.go.id. The sample in this study is Sharia Banking Statistics (SPS) from 2016 to 2019 which comes from Sharia Banking Statistics (SPS) obtained from the Financial Services Authority (OJK) website with the link www.ojk.go.id which is published every month. . In this study, the data used in the form of secondary data in the form of time series originating from the website of the Financial Services Authority (OJK) with the link www.ojk.go.id regarding the amount of mudharabah financing, Third Party Funds, and Return on Assets.

The data collection technique used is by using a study of documentation sourced from Islamic Banking Statistics (SPS) data for the 2016-2019 period which was obtained from the website of the Financial Services Authority (OJK) with the link www.ojk.go.id. The analysis of this study was carried out in stages as follows: multiple linear regression, normality test, classical assumption test (multicollinearity test and autocorrelation test), statistical test (coefficient of determination (R2), statistical $F$ test, and statistical $t$ test).

\section{Results and Discussion}

\subsection{Results and Discussion}

The normality test aims to test whether the data used in the regression model of the independent variable and the dependent variable or both have been normally distributed or not. A good regression model is to have a normal or close to normal data distribution. The following are the results of the normality test of research data:

Table 2. Normality Test Results

One-Sample Kolmogorov-Smirnov Test

\begin{tabular}{|ll|l|}
\hline & & $\begin{array}{l}\text { Unstandardized } \\
\text { Residual }\end{array}$ \\
\hline$N$ & & 48 \\
Normal Parameters & \\
& Mean & .0000000 \\
& Std. Deviation & .64384550 \\
Most Extreme Differences & Absolute & .193 \\
& Positive & 122 \\
& Negative & -.193 \\
Kolmogorov-Smirnov Z & & 1.336 \\
Asymp. Sig. (2-tailed) & & .056 \\
\hline a. Test distribution is Normal. & \\
\end{tabular}


Based on the table above, a significant value (2-tailet) was obtained $(0.056)>0.05$. So according to the basis of decision making, in the Kolmogorof Simirnov normality test, it can be concluded that the data is normally distributed.

\subsection{Multicollinearity Test}

Multicollinearity testing was conducted to explain the possibility of a relationship between one independent variable and another independent variable. To detect it, this research is done by looking at the Tolerance and Variance Inflation Factor (VIF) values for each independent variable provided that there are no multicollinearity symptoms, if the Tolerance value is $>0.100$ and the VIF value is $<10.00$.

Table 3. Multiconierity Test Results

\begin{tabular}{|r|r|}
\hline \multicolumn{2}{|c|}{ Collinearity Statistics } \\
\hline Tolerance & VIF \\
\hline & \\
.177 & 5.657 \\
.177 & 5.657 \\
\hline
\end{tabular}

Based on the table shows that the independent variables of mudharabah financing and third party funds do not occur multicollinearity because the value of vif does not exceed the value of 10 . Thus, the independent variable can be used to predict the dependent variable.

\subsection{Heteroscedasticity Test Results}

The heteroscedasticity test aims to test whether in the regression model there is an inequality of variance from the residuals of one observation to another. If the variance of the residuals from one observation to another is constant, then it is called homoscedasticity and if it is different it is called heteroscedasticity. A good regression model is homoscedasticity or there is no heteroscedasticity (Ghazali, 2013). Based on the results of data processing, the significant value for each dividend variable is greater than 0.05 . Thus the data shows that there is no heteroscedasticity.

\subsection{Auto Correlation Test}

The autocorrelation test aims to test whether in the regression model there is a correlation between the confounding error in the t-period and the confounding error in the t-1 (previous) period (Ghazali, 2013). Based on data processing, the Durbin Watson value is 0.638 . The Durbin Watson value is greater than $(-2)$ and less than $(+2)$. Thus, there is no autocorrelation in the data.

\subsection{Multiple Linear Regression Analysis}

Based on data analysis, the multiple linear regression equation in this study is: $\mathrm{Y}=$ $3.938-720 \mathrm{PM}+0.017 \mathrm{TPF}$

From the results of the multiple regression equation above, it can be explained as follows:

The constant (a) of 3.938 states that if the variables of third party funds and return on assets are considered zero, then the variable of mudharabah financing is 3.938. The regression coefficient for third party funds is -0.720 which states that if third party funds increase by $1 \%$, while the return on assets variable is considered constant, it will cause mudharabah financing to decrease by -0.720 . The return on asset regression coefficient of 
0.017 states that if the return on assets increases by $1 \%$, while the third party funds variable is considered constant, it will cause mudharabah financing to increase by 0.017 .

\subsection{Partial Test ( $\mathrm{t}$ Test)}

Based on table 6 above, the following results are obtained:

1. The sig value of third party funds is $0.001<0.05$ and the $t$ value (3.425) is greater than the $t$ table value (1.679). It can be concluded that the third party fund variable has a significant and significant contribution to the mudharabah financing variable.

2. Furthermore, the return on assets variable obtained a sig value of $0.210>0.05$ and the tcount value (2.390) is greater than the t-table value (1.679). The variable return on assets has an effect and is not significant on mudharabah financing.

\subsection{Simultaneous Test (F Test)}

Based on data analysis, it is known that the calculated $F$ value $(91,551)$ is greater than $\mathrm{F}$ table 3.20. So F count $>\mathrm{F}$ table, the third party funds and return on assets variables have a simultaneous effect on mudharabah financing.

\subsection{Coefficient of Determination $\left(\mathbf{R}^{2}\right)$}

Based on the correlation regression value of 0.896 , it means that together third-party fund savings and return on assets to mudharabah financing have a close and positive contribution. Then the adjusted R Square value. Where the value (R2) is 0.794 (79.4\%). So it can be said that $79.4 \%$ of the variation in the dependent variable, namely mudharabah savings and mudharabah deposits in the model can explain the mudharabah financing variable for Islamic Commercial Banks while the remaining $20.6 \%$ is influenced by other variables outside the model.

\subsection{The Effect of Third Party Funds on Mudharabah Financing}

Based on the results of the study, it shows that third party funds have an effect on mudharabah financing at Islamic Commercial Banks. This research is in line with the results of research conducted by (Paramita, 2019)(Tripuspitorin, 2019)(Saleh, 2020) that third party funds have a significant effect on mudharabah financing. It can be concluded that when third party funds are increased, it will increase mudharabah financing at Islamic Commercial Banks.

\subsection{The Effect of Return on Assets on Mudrabah Financing}

Based on the results of data analysis shows that return on assets has no effect on mudharabah financing. So that research is not appropriate (Miqdad, 2017)(Yolanda, 2018) which states that return on assets has a significant effect on mudharabah financing. However, this study is in line with the results of research conducted by (Aristi, 2018) which states that returns on assets have no effect on mudharabah financing. This means that an increase in return on assets will not be able to increase mudharabah financing at Islamic Commercial Banks.

\subsection{Effect of Third Party Funds and Return on Assets on Mudharabah Financing}

The results showed that all the independent variables of third party funds and return on assets had a positive and significant effect on mudharabah financing. This result is certainly in line with previous research conducted by (Miqdad, 2017) (Aristi, 2018) (Saleh, 2020) which states that an increase in third party funds and return on assets will be able to increase mudharabah financing at Islamic Commercial Banks. 


\section{Conclusion}

Based on the results of existing research where the conclusions that can be drawn are that partially only third party funds have a positive and significant effect on mudharabah financing at Islamic Commercial Banks. Meanwhile, return on assets has no effect on mudharabah financing at Islamic Commercial Banks. Furthermore, simultaneously the two independent variables, namely third party funds and return on assets, have a positive and significant effect on mudharabah financing at Islamic Commercial Banks.

\section{Acknowledgments}

Our gratitude goes to the Deputy for Research Strengthening and Development of the Ministry of Education, Culture, Research and Technology for funding the novice lecturer research (PDP) for the year 2021.

\section{References}

Aristi, D. S. G. S. F. W. (2018). Pengaruh Financing To Deposit Ratio (FDR), Dana Pihak Ketiga (DPK) Dan Return On Asset (ROA) Terhadap Pembiayaan Musyarakah. Edunomika, 02(02), 213-224.

Ghazali, I. (2013). Aplikasi Analisis Multivariate dengan Program IBM SPSS 21 Update PLS Regresi. Semarang: Badan Penerbit Universitas Diponegoro.

Handayani, rma C. M. Q. D. P. (2021). Pengaruh CAR , ROA, dan NPF Terhadap Penyaluran Pembiayaan pada Bank Umum Syariah yang Terdaftar di Otoritas Jasa Keuangan (OJK) Periode Tahun 2012 - 2019. Akusisi: Jurnal Akuntansi, 17(01), 6481.

Ichsan, R. N., et al. (2021). Determinant of Sharia Bank's Financial Performance during the Covid-19 Pandemic. Budapest International Research and Critics Institute-Journal (BIRCI-Journal) Vol 4, No 1, Page: 298-309.

Iska, S. (2014). Sistem Perbankan Syariah Di Indonesia. Yogyakarta: Fajar Media Press. Kasmir. (2014). Dasar-Dasar Perbankan Edisi Revisi. Jakarta: Rajawali Press.

Kurniawan, E. (2020). Pengaruh Tingkat Bagi Hasil Dan Dana Pihak Ketiga Terhadap Nisbah Pembiayaan Mudharabah Dengan Capital Adequancy Ratio Sebagai Variabel Moderasi. Jurnal Ilmu Akuntansi, 18(2), 62-81.

Mandasari, J. (2021). Pengaruh Return On Asset (ROA), Financing To Deposits Ratio (FDR) Terhadap Non Performing Financing (NPF) Pada Bank Syariah Di Indonesia. Journal of Accounting, Finance, and Auditing, 3(1), 25-33.

Miqdad, C. A. M. (2017). Pengaruh Dana Pihak Ketiga (DPK), Return On Asset (ROA) Terhadap Pembiayaan Mudharabah Pada Bank Umum Syariah Tahun 2008-2012. Riset Dan Jurnal Akuntansi, 1(1), 42-47.

Mubarokah, D. I. D. I. (2021). Pengaruh Pembiayaan Murabahah, Musyarakah Dan Mudharabah Terhadap Profitabilitas Bank Umum Syariah. Jurnal Ilmiah MEA (Manajemen, Ekonomi, Dan Akuntansi), 5(1), 1447-1463.

Naf'an. (2014). Pembiayaan Musyarakah Dan Mudharabah. Yogyakarta: Graha Ilmu.

Paramita, V. S. L. E. G. P. D. (2019). Pengaruh Dana Pihak Ke Tiga (DPK), Capital Adequancy Ratio (CAR), Dan Financing To Deposit Ratio (FDR) Terhadap Profitabilitas Return On Asset (ROA) Dengan Pembiayaan Sebagai Variabel Intervening Pada Bank Syariah Indonesia (Studi Empiris Pada Bank Syaria, (Idx), $19-21$. 
Romdhoni, S. A. H. (2020). Pengaruh Financing To Deposit Ratio (Fdr), Dana Pihak Ketiga (Dpk) Dan Return on Asset (Roa) Terhadap Pembiayaan Musyarakah. Jurnal Ilmiah Edunomika, 2(02), 598-608. https://doi.org/10.29040/jie.v2i02.316

Saleh, S. N. D. M. (2020). Pengaruh Dana Pihak Ketiga, Tingkat Bagi Hasil Dan Non Performing Financing Terhadap Pembiayaan Mudharabah (Pada Bank Umum Syariah yang terdaftar di Bank Indonesia periode 2014-2018). Aktual: Journal of Accounting And Financial, 5(1), 14-24.

Sudarsono, H. (2013). Bank Dan Lembaga Keuangan Syariah: Deskripsi Dan Ilustrasi. Yogyakarta: Ekosoria.

Sulaeman, C. I. P. S. (2021). Pengaruh Pembiayaan Murabahah, Pembiayaan Mudharabah dan Pembiayaan Musyarakah Terhadap Profitabilitas. Al Maal: Journal of Islamic Economics and Banking, 2(2), 160-177. https://doi.org/10.31000/almaal.v2i2.3111

Tarigan, N. M. R., Setiawan, H. (2020). The Effect of Employee Competence on Increasing Employee Motivation in Sumut Bank of Sharia Unit, North Sumatera. Budapest International Research and Critics Institute-Journal (BIRCI-Journal) Vol 3, No 2, Page: $858-867$

Tripuspitorin, L. S. A. F. A. (2019). Analisis Pengaruh Dana Pihak Ketiga, Non Performing Finance Murabahah, Dan Inflasi Terhadap Pembiayaan Murabahah Pada Bank Umum Syariah Di Indonesia. Jurnal Maps (Manajemen Perbankan Syariah), 3(1), 52-64. https://doi.org/10.32483/maps.v3i1.30

Widardjono, A. A. (2021). Analisis Pembiayaan Mudharabah Bank Pembiayaan Rakyat Syariah Terhadap Nonperforming Financing di Indonesia Tahun 2015-2020. Jurnal Baabu Al-Ilmi, 6(1), 26-37.

Wildaniyati, I. N. B. A. (2020). Pengaruh FDR, NPF, ROA, CAR Terhadap Pembiayaan Mudharabah (Studi Empiris Pada Bank Umum Syariah Yang Terdaftar Di Bank Indonesia Pada Tahun 2015-2019). JAMER : Jurnal Ilmu - Ilmu Akuntansi, 1(2), 8693. https://doi.org/10.33319/jamer.v1i2.26

Wirman, N. A. (2021). Pengaruh Pembiayaan Murabahah, Mudharabah, Dan Musyarakah Terhadap Profitabiltas Returnon Assets Pada Bank Syariahmandiri. Jurnal Ilmiah MEA (Manajemen, Ekonomi, Dan Akuntansi), 5(2), 50-63.

Yolanda, D. R. N. (2018). Pengaruh Return on Asset (Roa) Dan Biaya Operasional Pendapatan Operasional (BOPO) Terhadap Tingkat Bagi Hasil Deposito Mudharabah Pada Bank Umum Syariah Di Indonesia. In Proceeding Seminar Nasional Politeknik Negeri Lhokseumawe (Vol. 2, pp. 1-129). 